boys. ${ }^{1467}$ This variation is due to differences in the definition of acne (that is, whether or not comedones were included in the definition). Bloch, defining acne as the presence of more than one comedone, examined 4191 children aged 6-19 (2076 children aged 12-17) and found that the prevalence of acne increased from $13 \%$ to $97 \%$ in girls (aged 6 and 17 respectively) and from $12 \%$ to $99 \%$ in boys. ${ }^{6}$ Burton et al, who defined acnè in a similar manner, reported a prevalence of $100 \%$ in girls aged 14 and boys aged $15 .{ }^{1}$ Fellows $e t$ al, who in a longitudinal study of 1500 children defined acne as the presence of papules and pustules but excluded simple comedones, reported an increasing prevalence, from $1.3 \%$ to $78 \%$ in girls (aged 10 and 15 respectively) and from $0 \%$ to $87 \%$ in boys (aged 10 and 16.5 respectively).

The apparent fall in the prevalence of acne in our study compared with that of Burton et al 20 years ago may not be important. ${ }^{1}$ We were careful to include a single comedone as representing acne vulgaris, but we cannot say that a "snapshot" view of acne on one day means that $15 \%$ of girls and $7 \%$ of boys are never going to develop acne. We agree with Kligman's argument that the social impact of acne is due to its severity and not simply its presence (which he assumed to be $100 \%) .{ }^{8}$ Of greater interest is the fall in the severity of acne over the past 50 years. It is difficult to compare the results of previous studies as they all used different scales for grading acne. For comparison with other studies we arranged our results into five groups: no acne, minimal acne, mild acne, moderate acne, and severe acne. In 1931 Bloch reported that $57 \%$ of boys and $19 \%$ of girls had moderate to severe acne. ${ }^{6}$ These figures had fallen to $30 \%$ and $20 \%$ in $1971^{1}$ and to $35 \%$ and $13 \%$ in $1981 .^{7}$ Proportionally there was an even greater shift from the mild to minimal or subclinical groups in this study: we were unable to find any girls with worse than mild acne and only $1.8 \%$ of the boys had moderate acne.

During the same period the proportion of 12-17 year olds referred for specialist dermatology opinions declined. In 1967, 275 new patients with acne were referred to this department, of whom 98 (36\%) were aged 12-17. In 1977 this proportion had fallen to 62 (31\%) of 203 referrals and in 1987 to $45(21 \%)$ of 217 referrals. The reason for the decrease in severity of acne is not obvious. It has probably been due to an increase in awareness of appearance, increasing availability and use of over the counter preparations, and better management of acne by general practitioners. The low number of teenagers seeking advice from chemists is almost certainly an underestimate of the value of the pharmacist as a source of advice as many parents consult chemists on behalf of their children.

The economic cost of acne is potentially enormous. In 1974 in the United States it was estimated at $\$ 314$ million dollars ( $£ 200$ million): $\$ 190$ million for doctors' fees, $\$ 24$ million for prescribed treatments, and $\$ 100$ million for over the counter preparations. ${ }^{910}$ Similar figures are not available for the United Kingdom, but if dermatologists saw similar numbers of patients - that is, 21 per 1000 population each year - the cost to the hospital budget would be about $£ 58$ million if the consultation for each new outpatient is estimated to cost $£ 50$. Our results suggest that most cases of acne are managed well within the community and by general practitioners at a much lower cost.

We conclude that adolescent acne seems to be much less troublesome than it was 20 and 10 years ago. This is probably because of more extensive use of over the counter preparations as well as more suitable treatment by better informed general practitioners. The role of the dermatologist in the management of acne in this age group is minimal other than in educating primary health care workers.

We thank the department of community medicine of Greater Glasgow Health Board; the Strathclyde department of education; and the headmasters, members of staff, and pupils of the schools visited. We are also grateful to Dr W J Cunliffe and to Procter and Gamble Health and Beauty Care Europe for a grant.

1 Burton JL, Cunliffe WJ, Stafford I, Shuster S. The prevalence of acne in adolescence. Brf Dermatol 1971;85:119-26.

2 Cunliffe WJ, Gould DJ. Prevalence of facial acne vulgaris in late adolescence and in adults. $\mathrm{Br}$ Med $\mathcal{F}$ 1979;i:1109-10.

3 Munro-Ashman D. Acne vulgaris in a public school. Transactions of the $S_{t}$ fohn's Hospital Dermatological Society 1963;9:144-8.

Finlay SE. Physical diseases in university students. Br Med f 1976;ii:1312-4.

5 Burke BM, Cunliffe WJ. The assessment of acne vulgaris: the Leed technique. Br 7 Dermatol 1984;111:83-92.

6 Bloch B. Metabolism, endocrine glands and skin diseases, with special reference to acne vulgaris and xanthoma. Br f Dermatol 1931;43:61-87.

7 Fellowes $H M$, Billewicz WZ, Thomson AM. Is acne a sign of normal puberty? A longitudinal study. $\mathcal{F}$ Biosoc Sci 1981;13:401-7.

Kligman AM. An overview of acne. I Invest Dermatol 1974;62:268-87

9 Stern RS, Johnson ML, DeLozier J. Utilization of physician services for dermatologic complaints. The United States, 1974. Arch Dermatol 1977;113 $1062-6$

10 Kraning KK, Odland GF, for the Acne Study Group. Analysis of research need and priorities in dermatology. III. Acne. $\mathcal{f}$ Invest Dermato 1979;73:434-42.

(Accepted 21 February 1989)

\title{
Availability of computed tomography of the brain in the United Kingdom
}

\section{Richard Langton Hewer, Victorine A Wood}

Department of Neurology, Frenchay Hospital, Bristol BS16 1LE

Richard Langton Hewer, FRCP, consultant neurologist Victorine A Wood, MPHIL, research assistant

Correspondence to: Dr Langton Hewer.

BrMed J 1989;298:1219-20
Computed tomography of the brain has been used in the United Kingdom since 1974. The technique is now generally accepted as invaluable for investigating and managing intracranial disease. It also has cost benefits, with a major reduction in expensive and invasive investigations. ${ }^{1}$ In 1985 Thomson found that 108 computed tomographic scanners were in operation in the United Kingdom. We carried out a study to assess the position in 1987.

\section{Methods and results}

This study was undertaken with the collaboration of the services subcommittee of the Association of British
Neurologists. Details of the methods are reported elsewhere. ${ }^{2}$ A computed tomographic scanner was defined as a machine that was capable of, and available for, scanning the brain without financial charge to the patient. Mobile, whole body, and privately operated scanners were included provided that the above criteria were satisfied.

We identified 135 head scanners in the United Kingdom in June 1987. This number included two mobile scanners and one scanner in a private hospital. The table details distribution through the United Kingdom. Overall there was one head scanner to every 421000 people. There was considerable disparity between the best provided region (East Anglia), which had a ratio of one head scanner for 284000 people, and the least well provided region (Oxford), which had a ratio of one head scanner for 827000 people. The distribution of scanning facilities within regions was also uneven. For instance, nine of the 11 health districts in the South Western region $(82 \%)$ had their own head scanner, whereas only three of the 16 health districts in the Northern region $(19 \%)$ had a scanner. Overall, 27.67 million people - nearly $49 \%$ of the total 
Number and distribution of computed tomographic head scanners (Fune 1987)

\begin{tabular}{|c|c|c|c|c|c|}
\hline Health region & $\begin{array}{l}\text { Population }{ }^{3} \\
\text { (millions) }\end{array}$ & $\begin{array}{c}\text { No of } \\
\text { health } \\
\text { districts }\end{array}$ & $\begin{array}{l}\text { No of } \\
\text { head } \\
\text { scanners }\end{array}$ & $\begin{array}{l}\text { Ratio of population } \\
\text { to head scanner } \\
\text { (thousands) }\end{array}$ & $\begin{array}{c}\text { No of } \\
\text { health districts } \\
\text { with no head scanner }\end{array}$ \\
\hline \multicolumn{6}{|c|}{ Health authorities } \\
\hline $\begin{array}{l}\text { North East Thames } \\
\text { North West Thames } \\
\text { South West Thames } \\
\text { South East Thames } \\
\text { Special health authorities } \$\end{array}$ & $\begin{array}{l}3 \cdot 77 \\
3 \cdot 49 \\
2 \cdot 97 \\
3 \cdot 62\end{array}$ & $\begin{array}{l}16 \\
14 \\
13 \\
15\end{array}$ & $\begin{array}{l}11(2) \\
8(4) \\
7 \dagger(1) \\
8 \ddagger(1) \\
8(8)\end{array}$ & $\begin{array}{l}290 \\
291 \\
371 \\
402\end{array}$ & $\begin{array}{l}9 \\
8 \\
7 \\
8\end{array}$ \\
\hline East Anglia & 1.99 & 8 & 7 & 284 & 2 \\
\hline South Western & $3 \cdot 18$ & 11 & 11 & 289 & 2 \\
\hline West Midlands & $5 \cdot 18$ & 22 & $15 \|$ & 345 & 13 \\
\hline North Western & 3.99 & 19 & 9 & 443 & 13 \\
\hline Trent & 4.63 & 12 & 9 & 514 & 5 \\
\hline Yorkshire & $3 \cdot 6$ & 17 & 6 & 600 & 11 \\
\hline Mersey & 2.41 & 10 & 4 & 603 & 7 \\
\hline Northern & 3.08 & 16 & 5 & 616 & 13 \\
\hline Wessex & 2.88 & 10 & 4 & 720 & 7 \\
\hline Oxford & $2 \cdot 48$ & 8 & 3 & 827 & 5 \\
\hline Wales & $2 \cdot 82$ & 9 & 7 & 403 & 4 \\
\hline Total & 50.09 & 200 & 122 & 411 & $114(57 \%)$ \\
\hline \multicolumn{6}{|c|}{ Health boards } \\
\hline Scotland & $5 \cdot 13$ & 15 & 11 & 466 & 10 \\
\hline Northern Ireland & $1 \cdot 56$ & 4 & 2 & 780 & 3 \\
\hline United Kingdom total & $56 \cdot 78$ & & 135 & 421 & \\
\hline
\end{tabular}

*Calculations for Thames regions include scanners at special health authorities, given in parentheses. tIncludes one in private hospital.

IIncludes one mobile scanner, providing a one day a week service to Hastings Health District.

London postgraduate teaching hospitals were established as special health authorities under section 11 of the NHS Act 1977.

Includes one mobile scanner, which served six health districts; was counted as only one scanner (in East Birmingham Health District).

population of the United Kingdom-lived in health districts and boards with no head scanning facility.

\section{Comment}

This study showed a considerable variation in the provision of computed tomography of the brain across the United Kingdom. The ratio of the number of scanners to the population varied by a factor of 2.9 from the best to the least well provided region, and more than half of the health districts and boards in the United Kingdom did not have their own head scanner. Does it matter that many health districts do not have their own head scanner?

Epidemiological studies have shown that a health district of 250000 people will generate about 38 patients with subarachnoid haemorrhage, 500 with head injury, 550 with stroke, and 25 with bacterial meningitis yearly. ${ }^{4}$ In addition, many other patients will have possible, but undifferentiated, intracranial diseasefor example, prolonged unconsciousness after an epileptic fit in a patient who also has a minor head injury. Other subacute neurological disorders include subdural haematoma, cerebral tumour, epilepsy, and dementia. In many instances it would not be appropriate for these patients to travel long distances to have brain scanning.

Overall, present evidence suggests that there is a case for having a head scanner in every large district general hospital. This was suggested as long ago as $1978^{\text {s; }}$ in 1987 we were still far from accomplishing this goal. At present only a small number of health districts have magnetic resonance image scanners, and it seems unlikely that computed tomography will be superseded in the foreseeable future.

This report is based on a paper given to the Association of British Neurologists at St Bartholomew's Hospital, November 1987.

1 Thomson JLG. CT scanners in the UK. British Institute of Radiology Bulletin 1985; October:B57-9.

2 Hewer RL, Wood VA. A repon on neurology services in the United Kingdom: number and distribution of consultants in adult neurology; number and distribution of CT head scanners. Bristol: Frenchay Hospital, Department of Neurology, 1988.

3 Chaplin NW, ed. The hospitals and health services year book 1988. London: Institute of Health Services Management, 1988.

4 Wade DT, Hewer RL. The epidemiology of some neurological diseases. International Rehabilitation Medicine 1987;8:129-37.

5 Bartlett JR, Neil-Dwyer G. A clinical study of the EMI scanner: implications for provision of neuroradiological services. Br Med $\mathcal{J} 1978 ; \mathrm{ii}: 813.5$.

(Accepted 17 February 1989)
Motion Sickness and

Laboratory, Israeli Naval

Hyperbaric Institute,

PO Box 8040, 31080 Haifa,

Israel

C R Gordon, MD, director

A Shupak, MD, physician

I Doweck, MD, physician

O Spitzer, BA, physiologist

Correspondence to: $\mathrm{Dr}$ Gordon.

BrMed f 1989;298:1220-1

\section{Allergic contact dermatitis caused by transdermal hyoscine}

\section{R Gordon, A Shupak, I Doweck, O Spitzer}

Hyoscine (scopolamine) given transdermally is widely used to prevent motion sickness. To our knowledge only three cases of delayed hypersensitivity to transdermal hyoscine have been reported. ${ }^{12}$ We report the clinical features of 16 cases of allergic contact dermatitis caused by transdermal hyoscine.

\section{Patients, methods, and results}

A total of 164 male naval crew members were treated for seasickness with transdermal hyoscine for several months (range 1.5 to 15 months). Allergic contact dermatitis caused by the drug was diagnosed in 16 men. The table summarises these patients' clinical characteristics. In all 164 cases transdermal hyoscine was applied as a patch to glabrous skin behind the ear. None of the patients had previously handled or had contact with hyoscine.

All 16 patients had pruritus and erythema at the site of the patch. The pruritus started after several hours and lasted for a few days, whereas erythema was clearly evident within 24 to 48 hours after the patch was applied. Placing the patch behind the other ear produced an identical local reaction. Removal of the patch was followed by regression of the lesion. Total resolution took up to 14 days, depending on the severity of the lesion. In all cases the allergic reaction reappeared when a new patch was applied. All lesions were confined to the site of application.

Clinical examination of the lesions showed circular areas of erythema, oedema, and vesiculobullous or eczematous response in various stages of resolution. They were clearly demarcated from the surrounding skin, reproducing the circular shape, $1.5 \mathrm{~cm}$ in diameter, of the patch. No other local or general allergic reactions were present in any patient.

Samples of hyoscine patches from the batch used by

Clinical data on 16 men with allergic contact dermatitis caused by transdermal hyoscine

\begin{tabular}{|c|c|c|c|c|}
\hline $\begin{array}{l}\text { Case } \\
\text { No }\end{array}$ & $\begin{array}{c}\text { Age } \\
\text { (years) }\end{array}$ & $\begin{array}{l}\text { Duration of treatment } \\
\text { before allergic response } \\
\text { (months) }\end{array}$ & $\begin{array}{l}\text { No of patches } \\
\text { applied/week }\end{array}$ & $\begin{array}{l}\text { History of } \\
\text { allergies }\end{array}$ \\
\hline 1 & 19 & 1.5 & $1-2$ & \\
\hline 2 & 20 & 2 & $2-3$ & \\
\hline 3 & 21 & 2 & 2 & \\
\hline 4 & 19 & 2 & 2 & \\
\hline 5 & 19 & 2 & 2 & \\
\hline 6 & 21 & 3 & 1 & Hay fever \\
\hline 7 & 21 & 3 & $1-2$ & \\
\hline 8 & 21 & 3 & 2 & Asthma \\
\hline 9 & 20 & 3 & 2 & \\
\hline 10 & 20 & 5 & $1-2$ & \\
\hline 11 & 20 & 6 & 2 & \\
\hline 12 & 20 & 7 & 2 & \\
\hline 13 & 22 & 9 & 2 & Milk \\
\hline 14 & 20 & 13 & 2 & Penicillin \\
\hline 15 & 21 & 15 & 1 & \\
\hline 16 & 20 & 15 & $1-2$ & \\
\hline
\end{tabular}

